\title{
Exploration of Balai Materia Medica Batu: Field- Trip Supporting Biotechnology Learning
}

\author{
Hasan Subekti \\ Department of Science Education \\ Universitas Negeri Surabaya \\ Surabaya, Indonesia \\ hasansubekti@unesa.ac.id
}

\author{
Herawati Susilo \\ Department of Biology \\ Universitas Negeri Malang \\ Malang, Indonesia \\ herawati.susilo.fmipa@um.ac.id
}

\author{
Ibrohim \\ Department of Biology \\ Universitas Negeri Malang \\ Malang, Indonesia \\ ibrohim.fmipa@um.ac.id
}

\author{
Hadi Suwono \\ Department of Biology \\ Universitas Negeri Malang \\ Malang, Indonesia \\ hadi.suwono.fmipa@um.ac.id.
}

\author{
Aris Rudi Purnomo \\ Department of Science Education \\ Universitas Negeri Surabaya \\ Surabaya, Indonesia \\ arispurnomo@unesa.ac.id
}

\begin{abstract}
Field trips provide an opportunity to learn about life in the real world through exploration activities. This descriptive study aims to describe the process and response of students to the action of field trips to Materia Medica Batu (MMB) to support biotechnology courses. The participants in this study were 97 science students who took part in biotechnology lectures in East Java, Indonesia. The student response question used as an instrument of inquiry. Text form data were analyzed descriptively through 5 rankings, namely (1) data provision, (2) bathing, (3) coding, (4) visualizing, and (5) abstraction using NVivo 12 for window software. The results of data analysis show testimonials that popularly called in succession are joy, memories, meaningful. The main reasons are (1) providing new experiences in making traditional herbal medicines, (2) recognizing medicinal plants that have never taught during college, and (3) directly seeing the process of cultural processes with experts. However, managing time is the most popular obstacle. This study concludes that the field trip to MMB shows the importance of positive feedback to improve the quality of biotechnology learning.
\end{abstract}

\section{Keywords—Biotechnology, field trips, learning}

\section{INTRODUCTION}

Biology is "a continuous search and circumvention of the nature of life" [1]; one of which is through field trips. Fieldbased learning is a large part of experiential pedagogy [2] which aims to enables the competencies of pre-service science teachers [3] including observation and inclusion [4]. Field trips are an active learning approach so that it has the potential to foster student learning motivation. Besides, field trip learning is valuable to providing chances for students to live the future [3]. In this study, the field trip is conducted in the Technical Implementation Unit (UPT) of Materia Medica Batu (MMB).

MMB is one of the research centers for medicinal plants [5], from the Health Office of East Java Province located in Batu City, East Java, Indonesia. The institution focuses on providing raw materials for medicine such as the running of seedlings and the management of plants. In academic purposes, it also releases standard plant tissue culture magazines and receives visits from schools, colleagues, and researchers. By visiting this place, MMB can give positive influence to students in terms of biotechnology learning. Thus, the experience will increase the quality of learning so as to make the learning itself meaningful [6]; [7]; [8], memorable [9]; [10];[11], joyful [12]; [13], and engaging [14]; [15] for students.

Several results of the investigation found that field trips produced positive responses from visitors [2], and therefore, some higher education institutions began to incorporate field trips in MMB in their teaching practices [4] for instance, Universitas Negeri Surabaya (UNESA) and Universitas Trunojoyo Madura (UTM). However, designing learning through field trips is inevitably challenging [3] and needs improvements over time. Management of time activities, distance, boarding, safety, bureaucracy, and suitability of the place of visit with the scientific content being studied include in the consideration.

The purpose of this study is (a) to explain the field trip activities in MMB to support biotechnology courses, (b) describe students' responses related to the field trip, (c) describe students' suggestions and expectations over the field trip activities. By observing those three aspects, the study answer three different problems on (a) the need for preservice science teachers to gain experience in practical examples taught on campus and the world of work; (b) the need to increase the quality of biotechnology learning associated with the demands of the world; and (c) the necessity in increase students' motivation through the field trip.

\section{METHOD}

\section{A. Participants}

This research was categorized as descriptive investigation [16]. Participants involved in this study were 97 of 108 students who took Biotechnology courses in the 6th semester of the 2017/2018 academic year at UTM Indonesia. They were both males and females. 


\section{B. Instrument Collection}

The instrument used in this study was a set of questions regarding the implementation of the field trip to $\mathrm{MMB}$, which was administered after the field trip. The data is in the various form of text regarding student responses, namely testimonials, findings, suggestions, and expectations of the field trips in MMB

\section{Data Analysis}

To analyze the qualitative data, the study used NVivo 12 . The data analysis rating consists of five grades [17], namely (a) provision of data through the recapitulation of the rule of data text data in Excel; (b) immersion or repetition reading of data text; (c) provision of encoded data, by indicating transcripts and analyzing data to find meaning; (d) visualization of data analysis decisions, and (e) abstraction (abstraction) or synthesis to produce an explanation.

\section{RESULTS AND DISCUSSION}

More detailed explanation of (1) general information on the field trip activities, (2) students' responses for the field trip, and (3) suggestions for improvements and expectations of the field trip is elaborated below.

\section{A. Formatting the Title}

The field trip activities are characterized as reinforcement for biotechnology course in Science Education Program in UTM conducted in even semester of the academic year 2018/2019. To be precise, the field trip held on May $9^{\text {th }}$, 2018. MMB is one of the centers of investigation for plant plants [5], which is located on Jalan. Lahor No. 87, Pesanggrahan, Batu District, Batu city, East Java, Indonesia [18], which focuses on the development of traditional medicine [19]. The following is the figure of MMB office.

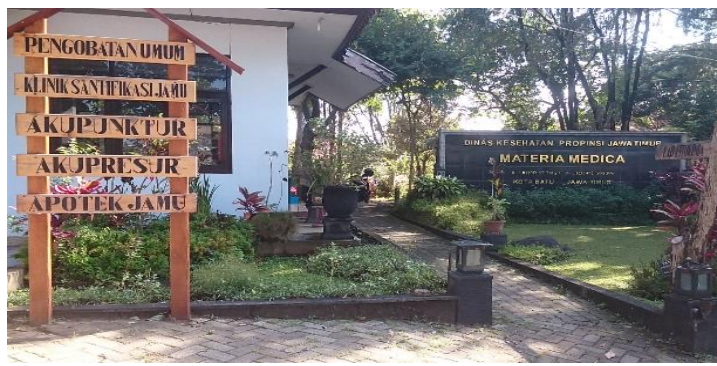

Fig 1. Meteria Media Batu Office

This institution has the vision "The Indonesian native of medicinal plants are used to produce raw medicine for the potential of Indonesia" [20]. The use of traditional medicine in the world is part of the history of human culture [19] By conducting the field trip in MMB, students can gather learning experiences to associate what they learn in class to the real world setting. The flow chart of the field trip to MMB is illustrated in Figure 2.

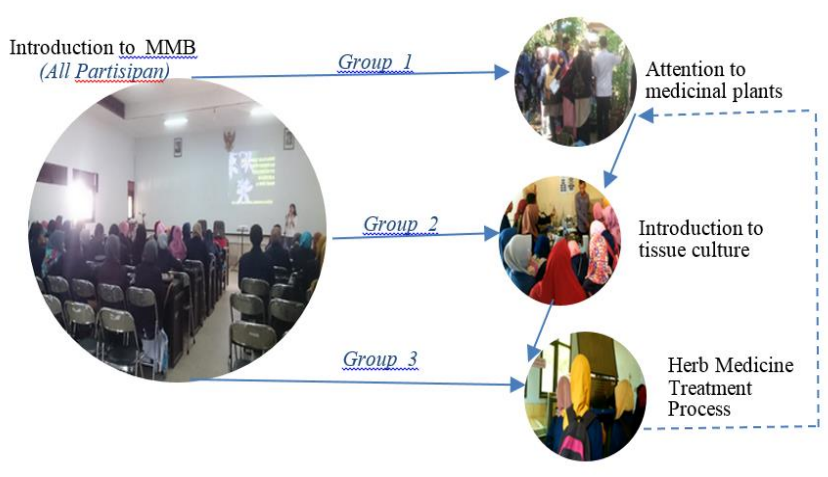

Fig 2. Field trip activity flow

During the field trip, three different groups were attending different sessions consecutively. There were three different sessions for learning, namely, the collection of medicinal plants grown in $\mathrm{MMB}$, the introduction of tissue culture conducted in $\mathrm{MMB}$, and the processes to produce herbs.

In the first session, the students were introduced to various medicinal plants species. Some of which are planted by purpose and the others are wild plants which are then identified extensively to unveil their potential for health [21][22]. The plants which are not relevant to medicine are replaced with the more valuable plants. The second session, the students were then visiting laboratory for tissue culture. They knew that the medicinal plants were sometimes propagated through tissue culture. The benefits of doing so is to produce high quality of medicinal plants in a limited time. In such, the students possessed procedural knowledge related to what to prepare and how to conduct tissue culture. Finally, in the third session, the students were invited to look for information of how to manage processing of medicinal plants after they were harvested. In terms of producing raw materials for medicine, the herbs also be tested to know the quality. Therefore, through those sessions, the students have the knowledge to strengthen their skills in biotechnology field.

\section{B. Students' Responses}

The field trip has the potential to motivate and inspire students to create memorable and meaningful educational experiences by studying cases in the real-world setting; and thus, allowing them to make connections between theories and practices. Regarding to challenges, participants were given a list and asked to choose the top three aspects, namely (a) joyful, (b) memorable, and (c) meaningful. 


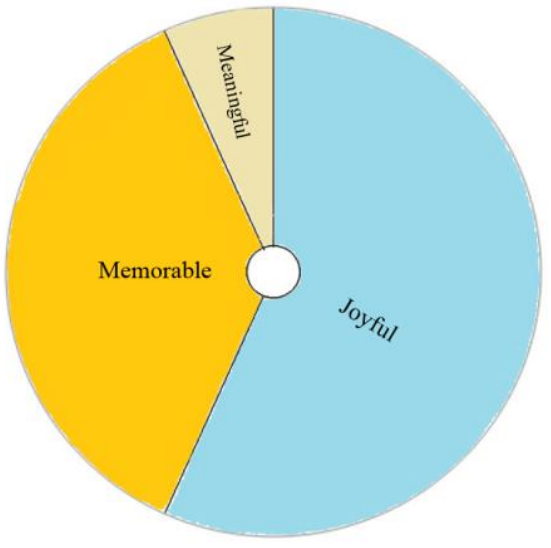

Fig 3. Main NVivo Map of Student Responses to the Field Trip

Figure 3 reveals that the most popular learning aspect with prevalent causes quality of learning which is directly related to (a) increasing knowledge, (b) being able to learn directly from the field, and (c) getting much knowledge from outside the study or campus. Joyful learning is a strategy, concept, and practice of synergistic learning from meaningful learning [23]. Learning experiences that are meaningful tend to challenge previous knowledge. Secondly, field studies were forgotten, primarily related to tissue culture. Tissue habits through liquid media and direct solid media can be seen directly in tissue culture mechanisms. Excellent reception from the committee from the MMB much impressed the participants. The intimate speaker and spokesperson in delivering and introducing the information relating to introducing Stone Media, various collections of medicinal plants, the process of dispensing herbal medicines and tissue culture. In line with this, the teaching and personal techniques described as meaningful by a student may not impress other students [24]. Meaningful learning in the context of teacher education is essential, especially prospective science students about what is meant to study [25] and how to study well. Third, this activity is meaningful. Digging up a lot of information and the lecture process while studying at first makes the lecture more meaningful. Learning to transcend the field trip embodies the original atmosphere that sparked student interest, giving them direct experience, and making learning more useful [26]. Meaningful learning arises in changes in students cognitive abilities

Also, the benefits of fieldwork widely regarded as a vital part of baccalaureate education and one of the most memorable forms of teaching and learning for students [27]. Some of the most prevalent causes are stretched in Figure 4 as follows.

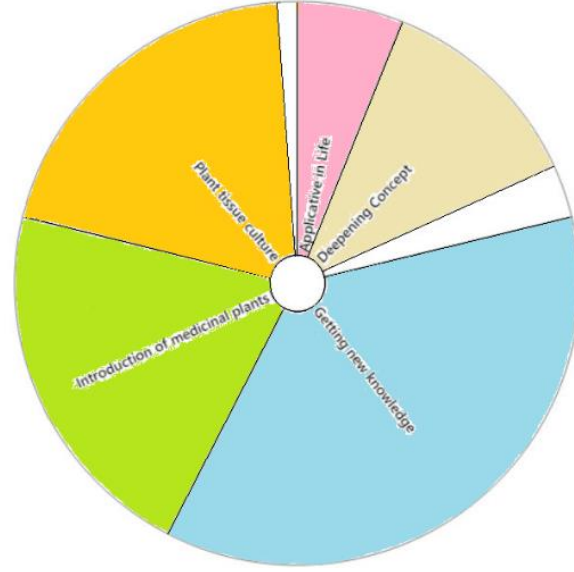

Fig. 4 Sunburst hierarchy chart of positive testimonials

\section{Reserve and Increase in Field Trips}

The most popular reserves for enhancement are (a) commenting on the steps to be taken in the field study, (b) the submission of material (especially the relationship to the culture of tissue) increasingly deep through full practice, (c) both without haste, and (d) need to be in the design of activities (rundown activities).

The most popular expectations are (a) field studies carried out as a sustainability program, where biotechnology is an elective subject that is always interested every year; (b) places visited by more than one place with a more extended period (h) teaches tissue culture techniques from the beginning and we also practice them.

\section{CONCLUSION}

This study concludes that the field trip to MMB shows the importance of positive feedback to improve the quality of biotechnology learning. This conclusion refers to the results of data analysis, which shows that testimonies which are generally seen to together are joy, memories, and meaning. The main reasons are (a) providing a new experience in making traditional herbal medicines, (b) recognizing medicinal plants that have never taught during college, and (c) looking directly at the cultural process of the series with experts. However, managing time is the most popular obstacle.

The implications of this study contribute to the field of fostering prospective science teachers. In this process, this study has implications for the development of expertise in the field of biotechnology teaching in tertiary rankings using available learning resources in the community (MMB). In the area, the scientific inquiry may use as enrichment material, reference material, comparative study, to improve the quality of learning.

\section{ACKNOWLEDGMENT}

We would like to thank the facilitating troops from MMB, Mr. Ali Topan (Researcher of Tissue Culture in MMB and Mr. Aris Hadrian as director of Biotechnology UTM. We also thank Universitas Negeri Surabaya and 
Universitas Negeri Malang for all facilities provided during writing process.

\section{REFERENCES}

[1] N. A. Campbell, L. A. Urry, M. L. Cain, S. A. Wasserman, P V Minorsky, and J B Reece, Biology: A Global Approach, New York: Pearson, 2017.

[2] J. B. Pauw, J. V. Hoof, and P. V. Petegem, "Effective field trips in nature: the interplay between novelty and learning," J. of Biol. Educ., vol. 59, p 21, 2018

[3] Wisanti and D. Astriani. "Bryological exploration: field-trip based learning to develop competencies of science teacher candidate," J. Phys.: Conf. Ser. vol. 1006 p 1, 2018

[4] G. Samarawickrema, and K. A. Raponi, "Field trip in the first week at university: perspectives from our LLB students, "The Law Teacher, vol 53, pp. 1, 2019.

[5] I. Tafliha, N. A. M. Nugroho, and I Martiningrum "Materia Medica Hall in Stone: Painting originally with the Use of the Principles of Water Conservation,” J. Mahasiswa Jurusan Arsitektur, vol. 3, pp. 1, 2015.

[6] A. L. Pesonen, and A. Piirainen, "Teacher students meaningful learning in widening learning worlds," Teach. Educ., vol. 30, pp. 1, 2019.

[7] Y. M. Huang and P. S. Chiu "The effectiveness of the meaningful learning-based evaluation for different achieving students in a ubiquitous learning context," Comp. \& Educ., vol. 87, pp. 243, 2015.

[8] E. Kostiainen, T. Ukskoski, M. R. Lyhty, M. Kauppinen, J Kainulainen, and Mäkinen T, "Meaningful learning in teacher education," Teach. and Teach. Educ., vol. 71, pp. 66, 2018.

[9] S. Basavaraju. S. Gaj, and A. Sur, "Object Memorability Prediction using Deep Learning: Location and Size Bias,” J. of Visual Comm. and Image Represent., vol. 59, pp. 117, 2019.

[10] S. Dymoke, "Poetry is not a special club: how has an introduction to the secondary Discourse of Spoken Word made poetry a memorable learning experience for young people?" Ox. Rev. of Educ., vol. 43, pp. 225, 2017.

[11] B. Mgxekwa, B. M. Scholtz, and M. Saayman, "A typology of a memorable experience at Nelson Mandela heritage sites," J. of Heritage Tour., vol. 14 p 325, 2018.

[12] P. Heywood, "Learning joyfully: An emotional and transformative experience," J. of Melbourne Stud. in Educ., vol. 46 p 33, 2010.

[13] A. Sriprakash, "Joyful Learning in rural Indian primary schools: an analysis of social control in the context of child-centered discourses," Compare: A J. of Comp. and Int. Educ., vol. 39 p 629 , 2009.

[14] R. Bourke, and J. Loveridge, "Beyond the official language of learning: Teachers engaging with student voice research," Teach. and Teach. Educ. vol. 57 p 59, 2016.

[15] K. Dreessen, and S. Schepers, "Foregrounding backstage activities for engaging children in a FabLab for STEM education," Int. J. of Child-Comp. Interact. vol. 20 p 35, 2019.

[16] H. Chu, and Q. Ke, "Research methods: What is in the name?," Lib. \& Information Sci. Res., vol. 39, p 284, 2017.

[17] L. Cohen, L. Manion, and K. Morrison "Research Methods in Education," New York: Routledge, 2018.

[18] R. Irawanto, D. A. Lestari, and E. E. Ariyanti "Laporan Kegiatan Tematik: Studi Pengelolaan Tanaman Koleksi dan Koleksi Penunjang untuk Mendukung Peningkatan Kualitas Koleksi Kebun Raya," Purwodadi: LIPI, pp. 14, 2012.

[19] Menkes, Regulation of the Minister of Health of the Republic of Indonesia Number 88 of 2013 concerning the Master Plan for the Development of Traditional Medicine Raw Materials (Jakarta: Ministry of Health of the Republic of Indonesia) pp. 5, 2013

[20] A. H. Bajafitri, "Technology for producing plants and aromatics UPT materia medika batu, Field Practicum Report," unpublished.

[21] H. V. Brahmantyo and R. Ariyanto, "System of decision support to determine which vegetation plants follow the type of disease that uses the topsis method," J. Informatika Polinema. vol. 2, pp. 66, 2016.

[22] O. S. Agnesa, H. Susilo, and S. R. Lestari, "Immunostimulant activity of single garlic extract in mice caused by Escherichia coli," Pharmaciana, vol. 7, pp. 105, 2017.

[23] S. Anggoro, W. Sopandi, and M. Sholehuddin, "Influence of joyful learning on elementary school students' attitudes toward science," J. Phys.: Conf. Ser., vol. 812 pp 1, 2017.

[24] A. A. Koehler, T. J. Newby, and E. D. Besser, "The eye of the beholder: using student narratives to explore memorable teachers," Educ. Rev., vol. 69, pp. 158, 2016.

[25] E. Kostiainen, and T. J. Pöysä, "Meaningful Learning in Teacher Education, Characteristics of," Encycl. of Teach. Educ., pp. 1-6, 2019.

[26] A. Ateșkan, and J. F. Lane "Promoting field trip confidence: teachers providing insights for pre-service education," Eur. J. of Teach. Educ., vol. 39, pp. 190, 2016.

[27] A. Bahri and A. D. Corebima, "The contribution of learning motivation and metacognitive skill on cognitive learning outcome of students within different learning strategies," J. of Baltic Sci. Educ., vol. 14, pp 487, 2015. 